\title{
SCOTTISH DIVISION
}

Since my last report in February 1976 the Scottish Division has continued to play an active part in the academic, educational, medico-political and social life of Scottish psychiatrists.

At Ninewells Hospital, Dundee, in March 1976 a discussion on liaison services in the general hospital was opened by Professor H. J. Walton and his colleagues from Edinburgh and by $\operatorname{Dr}$ A. B. Sclare of Glasgow. After a tour of the new hospital, papers were read on 'Sterilization' by Dr D. A. Primrose and 'The Psychiatrist and the List D School' by Dr H. Morton of Dundee. In June 1976 the Division visited Dykebar Hospital, Paisley, where a 300-bedded extension had recently been opened. The scientific meeting dealt with the relationship of psychiatry to other sources of counselling, and papers were read by representatives of the Scottish Council on Alcoholism, the Telephone Samaritans, the Marriage Guidance Council and the Church of Scotland. This proved to be an extremely successful and stimulating format for a meeting, and other meetings of this kind are planned.

In September 1976 the Division met at Crichton Royal, Dumfries, where the Chairman, Dr A. C. Tait, was host. Members heard short reports from representatives of a number of other bodies, including the Scottish Council for Postgraduate Medical Education, the Scottish Joint Consultants Committee, the Scottish Committee for Hospital Medical Services, the National Medical Consultative Committees, the Mental Disorder Programme Planning Group of the Scottish Health Services Planni ig Council and the Conference of Colleges and Faculties in Scotland. In addition to this concentrated diet of medical politics time was found for papers and discussion on 'Caring for the Disturbed and Potentially Violent Patient' and 'Legal Consideration in Giving Physical Treatment to Detained Patients' with contributions from Mr A. F. Neilson of the Scottish Central Legal Office and from a nursing tutor and a senior representative of COHSE.

In December 1976 the Division met in the Royal Edinburgh Hospital to hear reports from research units in and around Edinburgh. Papers were read by Dr Norman Kreitman and Dr Jack Ingram of the MRG Unit for Epidemiological studies in Psychiatry and by Dr George Ashcroft and Dr Peter Davies from the MRG Brain Metabolism Unit and Dr John Bancroft and Dr Ian Clark from the MRC Unit in Reproductive Biology. Later that day the Division's first Annual Dinner was held in the Thomas Clouston Clinic-perhaps better known to expatriates as
Craig House-and the Division welcomed as its Principal Guests the President, Professor Linford Rees, Lord McDonald, Chairman of the Mental Welfare Commission, and Dr Kenneth Davison, Chairman of the College Approval Panel which had so thoroughly and acceptably inspected Scottish psychiatry over the previous three years. The Division also welcomed as guests a number of new members of the College who had been successful in the Membership examination during the previous year. After dinner a superb cabaret was presented by a group of talented young Edinburgh psychiatrists, and their witty exposé of life in Morningside and beyond was received with rapturous acclaim. The evening was marred only by dense fog which surrounded the Edinburgh-Glasgow road and some stragglers did not reach home until well into the following day.

In March 1977 a meeting was held at Sunnyside Royal Hospital, Montrose, where Mr H. Ewing, MP, Parliamentary Under Secretary of State for Health Services in Scotland, joined members and delivered an interesting statement about Government policy for mental health services. He indicated that the Scottish Home and Health Department would be continuing to give added priority to the development of services for the mentally ill and the mentally handicapped and were aware of the need to support an expansion of services for the psychiatry of old age and for the treatment of alcoholism. He also suggested that the Department would shortly be undertaking a review of the 1960 Mental Health (Scotland) Act. Later in the day the Division heard papers on the Scottish Association for Mental Health from Mr Peter Clark, its new Director, and on the Psychiatric Services in Angus from Dr K. M. G. Keddie and Dr A. N. Munro. Papers on alcoholism and dementia were read by Drs Anne Guthrie and Alice Fleming.

The Summer meeting of 1977 was advanced to the month of May so that it could be associated with the College Quarterly Meeting in Inverness, and on Thursday, 5 May, members of the Division were delighted to welcome a number of colleagues from other parts of the British Isles to a discussion on aspects of mental handicap and child psychiatry, with papers from Drs G. Blamire, J. Bell, T. L. Pilkington, D. A. Primrose, W. T. Fraser, Cecilia M. Brebner, J. F. McHarg and I. G. Menzies.

In September 1977 the Division met at the Royal Scottish National Hospital, Larbert, where the meeting was devoted to a discussion on confidentiality based on the College memorandum published in News and Notes in January 1977. The speakers 
included Dr Richard Simpson, Miss Dorothy Broadman, Senior Social Work Adviser, Mr J. C. Anderson, Deputy Unit Leader, Scottish Special Housing and Dr I. E. Thomson of the Department of Medical Ethics and Education of the University of Edinburgh.

On 2 December 1977 the Division will meet in Glasgow to hear reports of research work in the Department of Psychological Medicine in the University of Glasgow and from the Department of Pharmaceutical Technology in the University of Strathclyde, the MRC Virology Unit and the MRC Blood Pressure Unit. The Second Annual Dinner will be held in the Royal College of Physicians and Surgeons of Glasgow when it is again intended that newly admitted members of the Division will be received as guests and welcomed by the President.

Programmes of meetings for 1978 are in preparation. We meet at Gogarburn Hospital, Edinburgh, on Io March; the Summer meeting and AGM will be held on 16 June, the place yet to be decided. Further meetings will be held on 22 September and I December 1978 .

In addition to all these activities the Specialist Sections of the Division have continued to have a very active programme of meetings and weekend conferences. The Executive Committee has met six times each year and has dealt with a considerable volume of important business. Amongst the items of particular significance have been the production of a report of a working party chaired by $\mathrm{Dr} J$. W. Affleck on 'The Psychiatrist's Contribution to the Care of the Elderly'. This report has been circulated to Health Boards, Local Health Councils, Directors of Social Work and a number of other interested

\section{TO OVERSEAS MEMBERS}

It is possible for issues of the British Fournal of Psychiatry and College papers to be sent to Fellows, Members and Affiliates overseas by Air Mail on payment of an additional annual charge, as indicated below.

$\begin{array}{lccc}\text { Bulletin } & \begin{array}{c}\text { Journal and } \\ \text { only }\end{array} & \begin{array}{c}\text { Meetings } \\ \text { only }\end{array} \\ \text { Europe } & £ 1.26 & £ 4.20 & 66 \mathrm{p} \\ \text { Zone A } & £ 1.20 & £ 6.24 & 54 \mathrm{p} \\ \text { Zone B } & £ 1.26 & £ 7.44 & 64 \mathrm{p} \\ \text { Zone C } & £ 1.50 & £ 9.96 & 88 \mathrm{p}\end{array}$

Those wishing to take advantage of this service should notify the Finance Officer of the College, who will let them know the appropriate rate, which varies from country to country. parties, and there is encouraging evidence that the Scottish Home and Health Department plan to accord higher priority to this aspect of the mental health service. There have also been a number of meetings with representatives of the Scottish Universities and with the Scottish Home and Health Department regarding staffing and training in psychotherapy, and the SHHD are now actively studying the implications of the separate designation of consultants and senior registrars in psychotherapy in Scotland. Members of the Executive Committee have had joint meetings with the Scottish Branch of the Institute of Health Service Administrators to discuss mutual problems in the administration of the Mental Health Services, and we have also had joint discussions with the Scottish Branch of the Royal College of Nursing and with the Association of Psychiatric Nurse Tutors in Scotland. Representatives of the Division have continued to play an active part in the College approval exercise. Dr J. K. Binns has now stepped down as Chairman of the Approval Panel and has been succeeded by $\mathrm{Dr}$ W. E. S. Kiernan of Glasgow who has recently returned from spending a year as a WHO adviser in India.

Currently under discussion is a proposal to meet Scottish Members of Parliament who have expressed an interest in mental health matter 3 in order to discuss further ways in which the Scottish Mental Health Service can be improved.

I hope that any member of the College travelling in Scotland on holiday or on business will try to attend one of our meetings, where a warm welcome is assured.

\section{G. C. Tmmury, Divisional Secretary}

\section{PAPERS FOR THE ANNUAL MEETING, 1978}

The Programmes and Meetings Committee invites members of the College to submit papers on miscellaneous topics for presentation at the Annual Meeting, which is to be held on 4, 5 and 6 July 1978 . Depending on the number offered, the Committee is prepared to make arrangements for parallel sessions to enable as many papers as possible to be read. I would be grateful to hear from members who have papers which they would like to present. The closing date for the receipt of summaries is 28 February 1978.

C. M. B. PARE Honorary Secretary, Programmes and Meetings Committee 